\title{
Juno and the Paycock: Hitchcock e a adaptação de um clássico do teatro irlandês
}

\author{
Khayles Nobrega Pereira Alves \\ Doutoranda em Letras pela Universidade Federal \\ da Paraíba. \\ khayles.nobrega@gmail.com
}

Resumo: Mestre da linguagem fílmica, Hitchcock teve destaque ao adaptar para o cinema obras literárias consideradas "menores", abstendose de levar às telas grandes clássicos. Uma exceção para essa regra foi Juno and the Paycock, baseado no drama homônimo do dramaturgo irlandês Sean O'Casey. Sucesso de crítica na época de seu lançamento, o filme, hoje, é visto com certo desdém, sob a alcunha de "teatro filmado". Nosso trabalho analisa como o diretor tentou transpor o texto teatral para a película, adotando estratégias que buscavam fazer jus à peça adaptada, mas que produziram significações diversas no tocante a personagens e suas motivações ideológicas, afetando e, sobretudo, rebaixando o estatuto dramático das caracterizações femininas.

Palavras-chave: Adaptação fillmica; Alfred Hitchcock; Sean O'Casey

\author{
Sandra Améla L. Cirne de Azevedo \\ Professora Doutora do Programa de Pós- \\ Graduação em Letras da Universidade Federal da \\ Paraíba. \\ lunasand@uol.com.br
}

Abstract: Master of filmic language, Hitchcock achieved great success in adapting "minor" works of literature, refraining from taking classics to the screen. An exception to this rule was Juno and the Paycock, based on the eponymous drama by lrish playwright Sean O'Casey. Successful among the critics at the time of its release, the film today is viewed with disdain under the category of 'filmed theater.' Our work examines how the director attempted to adapt the theatrical text to film, using cinematic resources in order to make justice to the original, though, in fact, producing distinct changes in characters and their ideological motivations, affecting and, above all, lowering the dramatic status of the female characters.

Keywords: Film adaptation; Alfred Hitchcock; Sean O'Casey 

Para Hitchcock, o sucesso da adaptação de uma obra literária parecia ser proporcional ao grau de dissociação entre o texto e o filme. Obras menos pretensiosas, que permitiam maior liberdade de adaptação e, portanto, de apropriação, constituiriam um excelente ponto de partida para a criação cinematográfica: haveria o reaproveitamento de uma boa ideia, a ser remodelada e modificada sem compromissos com a obra original. É o caso, por exemplo, de Os pássaros (1963), filme baseado no livro homônimo de Daphne du Maurier e do qual, em entrevista concedida ao cineasta francês François Truffaut e publicada no livro Hitchcock/Truffaut, Hitchcock diz não se lembrar: "o que faço é ler a história apenas uma vez e, se eu gostar da idéia básica, simplesmente esqueço tudo sobre o livro e começo a criar cinema" (TRUFFAUT, 1985, p.71). ${ }^{1}$

A adaptação fílmica de obras-primas da literatura, por outro lado, é vista por Hitchcock como certa desonestidade por parte do cineasta: para ele, o mérito desse tipo de filme residiria no mero reaproveitamento do trabalho e da criatividade do escritor. Além disso, o sucesso desse tipo de adaptação lhe parecia um objetivo praticamente inexequível, uma vez que a inventividade cinematográfica estaria comprometida como consequência da limitação imposta pela necessidade de se manter fiel às especificidades da composição textual. Embora tal perspectiva nos pareça hoje questionável, senão ingênua, sobretudo depois das contribuições das chamadas "teorias da recepção" acerca da abertura das significações textuais a cada leitor e a cada leitura, os desconstrucionistas mais radicais chegando a fazer coro com Barthes, para decretar "a morte do autor", não se deve, contudo, lançar mão de um anacronismo crítico para avaliar a postura de um diretor que, afinal, firmou-se como um gênio da arte cinematográfica. Fato é que Hitchcock descartou a possibilidade de adaptar grandes clássicos da literatura, 
como Crime e Castigo: "Ainda que adaptasse, o resultado não seria nada bom (...) nos romances de Dostoievski há muitas, muitas palavras, e todas elas têm uma função" (TRUFFAUT, 1985, p. 71-72). Sob essa perspectiva, dado que uma obra-prima se caracterizaria justamente por um certo grau de perfeição, que seria maculado pela intervenção do diretor e de sua equipe, bem como pela transposição da obra para uma outra linguagem, o cineasta considerava sábio evitar lançar-se a esse tipo de empreendimento.

Essa opinião de Hitchcock parece ter sido reforçada pela experiência de feitura e de lançamento do seu segundo filme falado, Juno and the Paycock, de 1929. A película baseia-se na famosa peça homônima de Sean O'Casey e, curiosamente, a despeito das complicações de lidar com a dinâmica, ainda em desenvolvimento, de gravações incluindo recursos sonoros, acabou sendo a obra com mais diálogos na carreira do cineasta. Diante dessa informação, nosso primeiro pensamento pode ser o de que Hitchcock tenha sido motivado por certo deslumbramento a explorar ao máximo esse novo atrativo cinematográfico, utilizando-o de forma mais equilibrada e artística em suas produções seguintes. A verdadeira razão para a presença tão marcante de falas no filme Juno and the Paycock, contudo, parece não se dever a inovações tecnológicas, remetendo-nos a uma outra questão técnica: a da adaptação de uma peça teatral.

Juno and the Paycock conta a história dos Boyle. Trata-se de uma família proletária residente em um tenement, espécie de cortiço que se estabeleceu em antigas moradias burguesas abandonadas em Dublin. Diversas famílias ocupam a mesma construção, habitando um dos cômodos, que faz as vezes de apartamento. A família Boyle é composta por quatro pessoas: uma filha trabalhadora, que se encontra em greve; um filho com condições físicas e psicológicas comprometidas por seu envolvimento na 
guerra civil irlandesa; um pai, desempregado e beberrão, que se exime da responsabilidade de conseguir emprego; e, por fim, uma mãe que se esforça para sustentar sua família e não apenas é a principal fonte de recursos financeiros da casa, mas cuida dos demais e pacifica os ânimos, na difícil convivência entre eles. Ao receberem a notícia de que um parente distante lhes deixara uma herança, a família acaba contraindo dívidas incondizentes com suas posses, antes mesmo de descobrir que, por um erro do escrivão, não poderá receber o espólio. A situação se torna ainda mais trágica quando sabemos que, devido à descoberta desse erro, o escrivão foge e deixa grávida a moça, de quem se tornara noivo. Por fim, o filho acaba assassinado e as mulheres decidem deixar a casa e o pai, cujo alcoolismo parecia mais forte do que sua afetividade para com a família.

Considerada uma das obras-primas do teatro irlandês moderno, o texto de Juno and the Paycock apresenta ainda maior dificuldade em sua lide cinematográfica do que Hitchcock dá a entender em sua declaração sobre o porquê de não gostar de adaptar clássicos. É que não se trata de recriar uma narrativa transformando-a em cena, como aconteceria com um romance, mas de transpor para uma nova linguagem cênica um texto já originalmente pensado para a encenação. André Bazin afirma que esse tipo de texto, isto é, o texto dramático, serve como uma espécie de "cristalização" que preserva, em si, todo o espetáculo: "concebido em função das virtualidades teatrais, o texto já as traz todas neles. Determina os modos e um estilo de representação, já é, em potencial, o teatro. Não é possível a um só tempo decidir ser fiel a ele e desviá-lo da expressão para a qual tende" (BAZIN, 1991, p. 130). Assim, o texto teatral, ainda quando modificado em relação a sua ambientação ou submetido às técnicas de narração, parece, seguindo esse pensamento, ser capaz de assegurar fidelidade à peça como um todo. Obviamente 
esse é também um raciocínio questionável. Embora um filme como Romeu + Julieta, de Barz Luhrmann, tenha fortíssimas conexões, verbais e estruturais, com a peça renascentista original traçada em detalhes pelo punho do grande Shakespeare, não há dúvidas de que a releitura do diretor australiano, fiel como se manteve ao texto dramático em sua tessitura dialógica, projetou sobre a tragédia shakespeareana uma gama tão extraordinária de significações contemporâneas que permitiu ao cineasta apor sua própria assinatura por sobre aquela do gênio renascentista, que, em relação ao filme, passa a figurar quase como em palimpsesto.

Bazin, falando do lugar que até hoje ocupa na história da teoria fílmica, julgava o texto teatral como um "falso amigo" do diretor cinematográfico, por passar a ilusão de já fornecer os elementos necessários à composição cênica. Na verdade, assevera Bazin, apenas a partir do momento em que a versão cinematográfica se mostra autônoma em sua linguagem e meios de produção próprios é que ela pode corresponder ao grau de excelência da peça, por meio "não de uma fidelidade ilusória de decalcomania - [mas] pela inteligência íntima de suas próprias estruturas estéticas, condição prévia e necessária para o respeito das obras que ele investe" (1991, p. 98). Para Bazin, em sua visão do cinema enquanto janela para a realidade, era possível advogar um realismo fílmico que subjugaria a ilusão, ao adotar explicitamente o artificialismo teatral como forma de representação, daí ele próprio recomendar, para adaptações cinematográficas de peças teatrais, a consecução da obra como um "teatro filmado". Para ele, as potencialidades do próprio cinema, em sua vocação para o realismo, não apenas permitiriam incorporar o artificialismo da encenação, mas ao fazê-lo, deixariam sua própria marca distintiva de representação naquela "realidade" artística. Discussões teóricas à parte, no que se refere ao texto fílmico baseado na obra de 
O'Casey, a despeito de as críticas da época lhe serem elogiosas, referindo-se a Juno and the Paycock como "próximo de uma obra prima" (TRUFFAUT, 1985, p. 69), o próprio Hitchcock não partilhava desse ponto de vista. As dificuldades técnicas de levar às telas um texto original que considerava em tudo bem-acabado, aparentemente impassível de modificações, fizeram o diretor desaprovar o resultado de sua película:

Apesar de ter lido a peça repetidas vezes, não conseguia enxergar um modo de narrá-la de forma cinematográfica. [...] Fotografei a peça tão imaginativamente quanto possível, mas do ponto de vista criativo, não foi uma experiência agradável. O filme teve comentários muito bons, mas na verdade eu tive vergonha, porque não tinha nada a ver com cinema. Os críticos exaltaram o filme, mas eu fiquei com a impressão de estar sendo desonesto, de ter roubado algo. (TRUFFAUT, 1985, p. 69, tradução nossa)

Talvez justamente pelo fato de a passagem dos anos ter sido acompanhada de um desenvolvimento da linguagem cinematográfica, definindo de forma mais clara os domínios e as qualidades da sétima arte, as críticas mais atuais parecem concordar com as palavras do diretor e não costumam ser nada generosas. A fidelidade à peça, tal como concebida (e lamentada) por Hitchcock nessa produção, perde o apelo positivo e passa a ser vista como um defeito, designada pejorativamente como "teatro filmado".

A concepção do que seja "fidelidade", entretanto, parece merecer maiores esclarecimentos. Se, por um lado, convencionou-se o julgamento de que "Juno é, como o próprio diretor observou, uma obra 'nãocinematográfica', uma peça de teatro levada intacta para o cinema, apresentada essencialmente da forma como era nos palcos" (MORGAN, 1994, p. 213, tradução nossa), 
por outro lado, como bem observa João Batista de Brito, "a propósito da figuração cinematográfica, [...] o material pré-fílmico (o cenário, os atores etc.) é um componente entre outros, e pode ter o seu valor estilístico alterado, digamos, pelo simples uso da câmera" (BRITO, 1995, p. 203). Assim, ainda que, de fato, com exceção do acréscimo de uma cena inicial contextualizando a história, e da supressão da cena final original, não haja alterações substanciais no texto de O'Casey, seria hoje ingenuidade supor que o filme de Hitchcock possa apresentar uma correspondência absoluta com a peça.

Primeiramente, cabe atentarmos para uma diferença fundamental entre a encenação teatral e a versão cinematográfica: enquanto numa peça como Juno não há narrador, mas acontecimentos que se desenrolam diante dos olhos do espectador, no cinema, invariavelmente, há uma narração: a intenção da montagem não é apenas valorizar o trabalho do ator, mas ressignificar as imagens captadas pela câmera:

No modelo de cinema clássico convencional é normal que o espectador assista ao filme inteiro sem ser levado a tomar consciência da interferência da narração autoral, [...] o envolvimento e a identificação são tamanhos que ele esquece a manipulação de que está sendo vítima e perde, ao menos instantaneamente, a habilidade de determinar o grau de interferência de uma instância narrativa" (BRITO, 1995, p.195-196).

Em sua tentativa de traduzir para a linguagem fílmica as noções contidas nos aspectos textuais de Juno and the Paycock, Hitchcock realizou um árduo trabalho de reelaboração formal do texto, ao mesmo tempo em que julgava estar a preservá-lo. Não é possível explicar a visão subjetiva do diretor para a concepção de cada cena, ou quais teriam sido as razões específicas para inserir 
determinados detalhes em alguns momentos e privar-se de fazer o mesmo em outros, nem mesmo saber até que ponto ele considerava que um artifício cinematográfico particular exercia função de mera transposição de medium ou implicava intervenção autoral. Podemos, no entanto, observar interferências como, por exemplo, o esforço em explorar o espaço diegético, realocando, sempre que possível, cenas que originalmente se passariam dentro do apartamento dos Boyle e que no filme ocorrem em ambientes externos.

Exemplo disso é a cena inicial da versão de Hitchcock. Na peça de O'Casey, a ação se passa na sala da família Boyle, onde somos apresentados a Johnny, Mary e Juno. Tomamos conhecimento de que Mary é uma moça engajada politicamente, a ponto de participar de uma greve em apoio a uma colega de trabalho pela qual sequer nutre simpatias. Juno, por sua vez, expressa sua desaprovação à militância de Mary: uma vez que lhe preocupa mais a urgência em garantir a subsistência da família do que a afirmação de um posicionamento ideológico, ela preferiria que sua filha se conformasse com a submissão a condições desfavoráveis no emprego, em vez de se aventurar a perdêlo em protestos que diminuem ainda mais a renda da casa. Enquanto as duas discutem notícias veiculadas pelo jornal, tomamos conhecimento, ainda por meio de suas falas, das circunstâncias políticas da morte do filho de uma vizinha, a senhora Tancred, e percebemos que Johnny, o jovem amputado em consequência de sua atuação política, sente-se deveras perturbado com a conversa. Assim, posto diretamente em contato com essas ações, cabe ao próprio espectador do teatro inferir o contexto político que se desenvolve como pano de fundo da trama. Por outro lado, ao testemunhar a cena familiar, o espectador é imediatamente instado a discernir traços caracterizadores do ethos das personagens. Fato é que, a partir da economia da arte teatral, o essencial da personalidade das mulheres 
e do jovem faz-se presente em cena. Entende-se, já na abertura da peça, que se inicia in media res, estarmos diante de uma mãe diligente, esforçada, uma espécie de matriarca, de uma jovem idealista, que advoga respeito absoluto aos seus princípios, e de um rapaz combalido física e psicologicamente.

Hitchcock, por sua vez, inicia o filme com uma cena que inexiste na peça, convidando-nos a testemunhar um aglomerado de homens na rua a ouvir um discurso a favor da pacificação da Irlanda, vitimada pelo confronto violento entre republicanos radicais e conservadores. $\mathrm{O}$ evento é interrompido por disparos de armas de fogo, desencadeando uma fuga alvoroçada dos cidadãos aflitos - imagem de desespero generalizado reforçada, em um exemplo de primor do uso metafórico da linguagem fílmica, pela exibição, em primeiro plano, de um gato que tenta escapar à confusão subindo em um poste. Nessa fuga, vemos refugiarem-se em um bar Jack Boyle, seu "bom amigo" Joxer e uma vizinha deles, Maisie Madigan. Em meio a uma rodada de bebidas que os dois homens habilmente se esquivam de pagar, é a Sra. Madigan quem os informa (e nos informa) que está sendo procurado na vizinhança um traidor, aquele que teria sido o responsável pela morte do filho da senhora Tancred. Claro está que esta cena fílmica também acaba por instruir o espectador acerca do ethos desses personagens, mas Hitchcock claramente desvia o foco fundamental dado pela peça de O'Casey às mulheres da casa, Juno e sua filha Mary, as verdadeiras protagonistas dessa obra teatral, concedendo aos dois bufões o privilégio de serem os primeiros personagens a aparecerem em cena.

A respeito do realce concedido às mulheres na peça de O'Casey, vale a pena retornar ao texto teatral para considerar a ironia implicada na tessitura de uma peça que é exímia em enredar questões políticas, sociais, religiosas e existenciais, sendo Juno uma representação rebaixada 
da grande deusa pagã em sua versão latina e Mary uma figuração decaída da virgem cristã. Juno (que não é o nome verdadeiro, mas apenas o apelido da personagem) certamente comanda a ação em toda a peça de O'Casey e justamente seu labor intenso, seu pragmatismo operatório, sua capacidade de mediação do núcleo familiar sempre ameaçado pela pobreza, pelo ativismo político, pelo alcoolismo, sua religiosidade e fé inabaláveis não apenas a mantêm de pé, mas emprestam-lhe a dignidade exigida a qualquer heroína trágica. No entanto, se a abertura da peça de O'Casey é dramática e impõe seriedade e elevação ao enredo, o filme de Hitchcock privilegia já à partida os personagens cômicos, o Capitão Boyle e seu amigo Joxer sendo um par de paspalhos, dois beberrões, bufões que trariam apenas risos à plateia, não fossem suas ações inconsequentes um contraponto dramático em relação à luta da própria Juno, ao drama do combalido Johnny, e ao sofrimento de Mary, em sua condição de grávida abandonada, sendo este, à época, o mais grave dos suplícios para as mulheres, "pior que a tuberculose", como nos diz explicitamente o texto teatral.

Não surpreende a força das mulheres na peça de O'Casey. A influência de Ibsen, cujas protagonistas fizeram tremer os palcos da Europa por suas ações transgressoras e contestatórias, patenteia-se explicitamente em Juno and the Paycock, já que algumas das peças do dramaturgo norueguês compõem o próprio cenário da peça irlandesa: três livros de Ibsen, espalhados sobre a mesa, são referenciados pelo Sr. Boyle com desdém, como livros tolos, costumeiramente lidos por Mary, dentre os quais, o primeiro citado é Casa de Bonecas, a obra-prima de Ibsen, centrada em uma protagonista que abandona marido e filhos, em recusa à hipocrisia da vida social burguesa.

O filme de Hitchcock, portanto, impõe um outro tom à recepção, negando às mulheres o lugar privilegiado que lhes cabe na trama de O'Casey. Contudo, 
imediatamente depois da abertura, o filme de Hitchcock conduz a dupla de malandros ao apartamento miserável dos Boyle. Esperando-os em casa, encontra-se Juno, que os observa em silêncio. Assim que se dão conta da presença da mulher, os bêbados tentam convencê-la de que suas andanças não se prestavam à vagabundagem, mas a uma procura bem sucedida por emprego. Cética, Juno expulsa Joxer e apresenta suas queixas quanto ao marido, que anda a se pavonear como capitão, quando apenas havia passado uma breve e tranquila temporada a bordo de um barco carvoeiro. Exibindo, portanto, uma imagem descabida, o Sr. Boyle leva a vida preguiçosamente, em vez de arranjar um meio de contribuir para o sustento da família. A partir daqui, peça e filme perfazem o mesmo caminho, como dissemos, sem grandes diferenças estruturais aparentes.

Entretanto, para além dos prejuízos na apresentação de Juno e de Johnny, que parecem ambos mais caricatos no filme, também a Mary de Hitchcock é bem menos complexa do que a de O'Casey, a versão fílmica havendo sonegado justamente a introdução disponibilizada pela dinâmica teatral, que enquadrava Mary na convivência com a família e realçava seu papel de militante, por meio de referências ao seu envolvimento na greve. Diríamos que o caráter de Juno, embora reafirmado a cada diálogo no qual toma parte, somente à medida que a ação do filme se encaminha em direção ao final adquire contornos de tragicidade. Quanto à trama paralela do medo vivenciado por Johnny, esta acaba sendo restaurada pela narração fílmica, que mantém constantemente sobre o personagem atribulado o foco imagético, capturando seu desespero por meio de planos, movimentos de câmera e montagem. Note-se, assim, que traços mais sutis de caracterização dramática e trágica são substituídos no filme por imagens mais concretas, Johnny parecendo, na versão de Hitchcock, o contraponto trágico aos bufões cômicos. Além de sua aparência grotesca, mutilado que se mostra 
em cena com um único braço, o realce dado pelo filme ao seu terno preto e à maquiagem sombria faz do jovem uma figura expressionista, mais cabível em um filme de terror do que em um drama tragicômico, e para isso contribuem técnicas cinematográficas diversas.

Nessa estética fílmica que privilegia a concretude imagética em detrimento das sutilezas da caracterização, não há dúvidas de que os traços ideológicos que emprestam a Mary sua grandeza de caráter e engendram seu pathos trágico se perdem e, assim, empobrecem fortemente a representação da personagem. Embora, como dito acima, se comparada a sua representação na peça de O'Casey, Juno se apresente no filme de forma mais caricatural; o fato de ser a mesma uma matriarca, de estar no comando de todos os demais personagens, operando sempre de forma pragmática, permite-lhe manter-se como protagonista e elevar-se na trama, à medida que a ação se vislumbra como trágica. Mary, entretanto, se ganha realce por sua beleza exposta na tela, perde muito em profundidade psicológica, uma vez que Hitchcock opta por dar continuidade aos acontecimentos da ação sem reinserir as informações que pertenciam à cena original escrita por O'Casey. A bem da verdade, o filme concede apenas dois rápidos momentos de destaque a Mary. Um corresponde ao seu luto na cena final e serve apenas de contraponto para a reafirmação do caráter de Juno. O outro, e de maior destaque, acontece após o anúncio de sua gravidez enquanto moça solteira, quando Jerry Devine - seu antigo pretendente, reaparece na tela com o intuito de conquistá-la, uma vez que seu noivo desaparecera. Claro que, reforçando o preconceito da época, Jerry Devine afasta-se rapidamente da moça, tão logo toma conhecimento da sua gravidez. Talvez pelo apelo dramático da cena gravada em close, talvez por ser o anúncio da gravidez a primeira desgraça de toda uma série da qual a família tomará consciência, desencadeando o anúncio das demais, o filme foi, curiosamente, rebatizado 
nos Estados Unidos com o nome de The Shame of Mary Boyle, a despeito do considerável "apagamento" da personagem no desenrolar dos acontecimentos. A opção por esse título parece refletir, ainda que de forma obviamente invertida, contestável, a importância da própria personagem na peça original que inspira o filme e na qual ficava evidente a derrocada da jovem revolucionária, que batalha por uma vida diferente, mais digna, mas acaba presa à miséria dos tenements, subjugada aos tabus sociais, condenada pela necessidade de criar um filho ilegítimo. Claro está que há, na composição do ethos de Mary Boyle, componentes incômodos a uma civilização que celebra o heroísmo individual e a moralidade puritana, em um sistema apregoado como favorável, estimulante, locus ideal para a realização do Eu, moldura em nada compatível com o cenário político irlandês evocado pela peça de O'Casey.

Outro exemplo de como Hitchcock explora a linguagem fílmica para narrar a ação está no mais característico recurso imagético utilizado em sua obra: a movimentação incessante da câmera, sempre acompanhando o diálogo dos personagens sob algum ângulo sugestivo. O melhor exemplo da manipulação desse recurso encontra-se no trecho que corresponde ao segundo ato da peça. Trata-se de uma sequência particularmente longa e exaustiva, recheada de falas, que se prolonga no filme por 25 minutos. Numa tentativa de proporcionar maior dinamismo à cena, que na peça transcorre em um único cenário - a sala do apartamento dos Boyle -, Hitchcock apela para a montagem sob diferentes perspectivas e planos-sequência. Assim, uma personagem que permanece sentada em uma cadeira é focalizada de diferentes pontos do cenário. Do mesmo modo, ao invés de lançar mão do típico jogo de campo e contracampo, o diretor opta por filmar a maioria dos diálogos acompanhando os personagens com movimento externo de câmera, que desliza de um personagem a 
outro, conforme mudam os falantes, ou, ainda, exibindo em plano americano as ações das demais personagens, enquanto a voz do falante prossegue em off.

Quando recorre ao uso de câmera subjetiva, em uma metalinguagem que evidencia a ocorrência de "teatro filmado" como recurso proposital, a imagem não transmite a visão de um dos personagens em cena, mas a de um observador às suas costas, remetendo à visão que se tem do palco no teatro. Durante os monólogos infindáveis de Maisie Madigan, Hitchcock mais uma vez brinca com essa metalinguagem, fazendo com que a câmera se atenha à personagem por algum tempo. A sensação causada por uma cena "estática" faz com que o discurso pareça ainda mais longo e enfadonho, se considerado em relação ao que se convencionou chamar de cinema clássico, hollywoodiano. Quando, mais uma vez, Madigan dá início a mais um tedioso monólogo, Hitchcock não repete a fórmula: durante a fala da personagem, sua voz permanecerá em off, enquanto a câmera vai focalizando os ouvintes, detendose por alguns instantes em cada um deles para registrar uma série de expressões de desconforto - refazendo, em seguida, o percurso de volta para enquadrar a falante vizinha. Ao constatar o número de imagens pacientemente acompanhado pela câmera, acentuando a longa duração do monólogo, o espectador tem em evidência seu caráter verborrágico. Esses recursos de focalização incidem também sobre a caracterização de Maisie Madigan e reforçam o estereótipo das mulheres como criaturas tagarelas, fofoqueiras, os personagens da peça apresentando-se no filme como extremamente tipificados.

No que diz respeito a Johnny, conforme já mencionamos, os efeitos de câmera tornam bem mais óbvia a relação entre o tormento do jovem e as notícias envolvendo a morte de Tancred: sempre que se fala no morto, o plano cada vez mais próximo dos olhos desesperados de Johnny não nos deixam escapar o 
nervosismo que, no palco, certamente não seria percebido com essa concretude que no filme se avulta em elemento de dramaticidade, ainda que evocada por uma via imagética que favorece mais o terror exteriorizado e estereotipado do que a profundidade da tortura psicológica. Nessa perspectiva, na última tomada, antes que a ligação de Johnny com a morte seja anunciada verbalmente, a sugestão de que o comportamento intranquilo de Johnny se deve não aos horrores da guerra, mas à inescapável culpa de ter participado da morte do ex-amigo, faz-se de maneira bastante objetiva, num efeito de crescente certeza: inicialmente, Johnny mostra-se enervado com a canção nacionalista entoada pelos presentes; depois, ao ouvir a ladainha do funeral de Robert Tancred, alteram-se sua expressão facial e também a corporal, bem como o ritmo de sua respiração; em seguida, quando o mobilizador de irregulares entra em cena, o oficial é mostrado pelo efeito de câmera subjetiva e, conforme se aproxima, sua imagem vai sendo encoberta por sombras, ao mesmo tempo em que parece maior, realçando o aspecto sinistro com que se apresenta para Johnny. Após o mobilizador deixar a sala, tendo anunciado que Johnny está sendo convocado para um interrogatório, o jovem permanece imóvel, e torna a olhar para a janela por onde entra a música do velório. Quando se mostra a janela em câmera subjetiva, no entanto, o som que adentra é o de tiros de arma de fogo. Esse mesmo recurso já havia sido exibido em uma cena anterior do filme e sua repetição torna evidente o comportamento agorafóbico de Johnny, que se enclausura no pequeno apartamento por temer a violência do conflito partidarista que toma as ruas de Dublin - conflito no qual ele estivera diretamente envolvido e cujas sequelas estigmatizaram seu corpo com a perda de um braço e com uma lesão permanente no quadril.

$\mathrm{Na}$ parcela do filme correspondente ao terceiro ato da peça, Hitchcock dispõe de maiores brechas no 
texto de O'Casey para conduzir o espectador a uma breve cena "arejada", ambientada fora da habitação dos Boyle e das longas conversas que por lá ocorrem. Como convém ao retrato da passagem do tempo, maior agilidade é conferida às cenas em que Hitchcock aponta para o sumiço de Bentham, noivo de Mary, e para a sua causa. Primeiramente, vemos a placa do escritório onde Bentham trabalha e, a seguir, a porta de sua sala, de onde sai um desalentado Jack Boyle a recordar, em voz off, as expectativas de sua família quanto à herança que receberiam. Em seguida, o nome de Charles Bentham é apagado da porta de seu escritório. Concluímos, assim, que a herança divulgada por Bethan não virá para concretizar os planos evocados pelas palavras que ecoam na mente de Jack Boyle, e, também que, após a constatação da impossibilidade de recebimento da herança pelo futuro sogro, Bentham foge, abandonando tanto o vínculo empregatício quanto o vínculo amoroso.

A cena que se sucede trata do espalhamento pela vizinhança da notícia sobre o não recebimento da herança e mostra Joxer e Mr. Kelly, um alfaiate, cochichando sobre a situação financeira da família Boyle. Mr. Kelly conta a Joxer que não haverá mais herança e, portanto, irá à casa dos Boyle reaver um terno cujo pagamento, ainda pendente, certamente não será realizado. Hitchcock inova mais uma vez na forma como é narrada a conversa "à boca pequena”. Em superclose, numa cena que lembra o beijo em cut up de Janela Indiscreta (1954), vemos, lado a lado, as cabeças de Joxer e a do alfaiate, que se alternam em seus papéis: ora um empresta a orelha à escuta dos lábios do outro para, depois, virar-se com os lábios visíveis ao lado do ouvido alheio. A cena ocorre na rua e Juno, que passa conduzindo Mary ao consultório médico, respondendo aos homens informa-lhes que o marido se encontra em casa. Assim, como a ação da peça de O'Casey foi concebida para um único cenário, Hitchcock reelabora esteticamente as 
cenas já prontas fornecidas pelo dramaturgo, situando-as nos corredores ou na entrada do tenement, a alguns passos do apartamento no qual toda a ação da peça se confina, e do qual mesmo o filme apenas em poucos momentos consegue se afastar.

Apesar do belo trabalho no que concerne a questões técnicas de narração cinematográfica, o filme de Hitchcock parece não fazer jus à força e à vitalidade da envolvente peça de O'Casey. No entanto, críticas como a apresentada por Rohmer e Chabrol no livro Hitchcock: the first fourty-four films parecem partir equivocadamente da premissa de fidelidade "absoluta"; uma vez que apenas o desconhecimento da peça de O'Casey explicaria os comentários tecidos pela dupla quanto ao tratamento dispensado pelo dramaturgo à religião, é de se supor que os tenham feito com base meramente na forma como ela foi apresentada por Hitchcock. Numa aparente tentativa de salvaguardar o cineasta, esses autores tentam justificar o que consideram a "mediocridade" do filme justamente com o argumento de que ele foi "fiel" a uma peça simplória, na qual o empenho do escritor residiria num proselitismo religioso, cuja obviedade constrangeria o próprio Hitchcock. Resignado em cumprir a inescapável imposição do estúdio de registrar em película tal texto, o diretor teria restringido sua ação a fazer simplesmente o que lhe havia sido solicitado, sem maior envolvimento: "Não há inventividade e nem sequer um desejo de inventividade na filmagem do script. Apesar de a peça de O'Casey ser fielmente seguida [...] é tratada por Hitchcock com absoluto desdém" (ROHMER; CHABROL, 1979, p. 23, tradução nossa).

A peça de O'Casey, pioneira no enfoque da classe proletária habitante dos cortiços de Dublin, retrata os impactos da guerra no cotidiano de uma família composta por tipos irlandeses comuns, como o desempregado e o alcoólatra, uma mãe abnegada que zela por manter a família 
unida, uma moça inteligente, socialmente engajada e com perspectiva de vencer na vida, e um jovem marcado física e psicologicamente pelos horrores da guerra, que tem envolvimento com o IRA. A religião é retratada como mais um dos elementos representativos da identidade nacional, sendo, inclusive, objeto de críticas na própria ação da peça. Ainda que o catolicismo seja incorporado especialmente pela figura da mãe, personagem mais dignificada pelo enredo, enquanto o ceticismo e o teosofismo encontram arautos menos admiráveis, a religião não ganha na peça uma dimensão maior do que a de servir aos propósitos da caracterização. Posicionamentos políticos, morais, religiosos e éticos são utilizados pelo autor para "ilustrar as filiações concorrentes que complicam a política do auto-interesse" (MORRISON, 1999).

Além disso, a preponderância do catolicismo na trama, a ponto de receber interpretações equivocadas, aparece em Hitchcock, mas não em O'Casey. Atentemos, por exemplo, para o desfecho do filme, que difere do final da peça. A última cena da versão cinematográfica mostra-nos Juno, após receber a notícia da morte do filho, a questionar a imagem da Virgem Maria, indagando-lhe onde estava no momento do assassinato de Johnny. Em seguida, Juno repete a prece feita pela senhora Tancred em seu cortejo do corpo do filho morto: "arrancai-nos nossos corações de pedra e dai-nos corações de carne e sangue. Arrancai este ódio assassino e dai-nos o Vosso infinito afeto!" (O'CASEY, 1965, p. 93). Na versão de O'Casey, após essa cena, segue-se outra, em que Jack Boyle e Joxer, embriagados, trazem a peça de volta a sua tônica principal, através de uma confusa discussão encerrada com a conclusão de que "o mundo todo anda num terrível estado de crise" (Id., p. 94). Assim, "aquilo que saltaria aos olhos de Rohmer e Chabrol como a controvérsia segundo a qual Hitchcock estava desconfortável com o 'catolicismo' da peça de O'Casey, indicaria, quando muito, 
que Hitchcock tornou católico um final relativamente sóbrio e niilista e, assim, diminuiu a ambiguidade e a ironia da peça" (MORGAN, 1994, p. 214).

Quando nos questionamos sobre as razões pelas quais Hitchcock teria escolhido alterar o final de uma história à qual afirma ater-se de forma estrita, supomos que o diretor tenha preferido conferir a seu filme um arremate mais catártico, apesar do marcante humor proveniente, especialmente, da dinâmica da dupla de ébrios, que recebe destaque durante boa parte da narração fílmica. Provavelmente pareceu ao diretor que o destino de Jack Boyle já se mostra determinado quando ele decide sair para beber, após receber a notícia da gravidez de Mary: sua reação frente à nova adversidade, a morte do próprio filho, é a repetição do comportamento inconsequente com que ele reagia às demais adversidades que o cercavam desde o início das desventuras da família Boyle. O final proposto por O'Casey, no entanto, não parecia ter a catarse como fim em si mesma, mas como meio de confirmação de um enfoque que se espraia para além do envolvimento do espectador com o sofrimento individualizado da família vitimada pela desgraça. Ele buscava, ao contrário, esclarecer que a tragédia individual dos personagens é diretamente influenciada pelo ambiente de miséria a que está submetido o cidadão de classe baixa, decorrente do estado de guerra em que a Irlanda se encontrava. Assim, ao tomar consciência do processo por meio do qual decorre a tragédia dos Boyle, o espectador não estaria sujeito a uma catequização dissimulada, mas à conclamação a uma nova ideologia cívica, voltada para o bem-estar civil. O próprio Hitchcock se mostra ciente desse propósito e tenta evidenciá-lo com a primeira cena, em uma espécie de prólogo, no discurso do orador de rua, mas a inclusão dessa cena inicial, forjada pelo próprio diretor, parece ter se dado apenas como estratégia facilitadora à compreensão da trama, pois no desenvolvimento e na finalização da 
ação, Hitchock parece perder de vista a dimensão política da peça de O'Casey, apostando na representação do sofrimento familiar como foco da trama.

Embora as declarações do próprio Hitchcock, que afirma ter se esforçado para ser o mais fiel possível à peça de Sean O'Casey, sejam de que não há mérito cinematográfico na adaptação fílmica de Juno and the Paycock, que seria melhor qualificada sob a denominação de "teatro filmado", não é sensato acreditar que a versão do cineasta corresponda à mera tradução do texto dramático para uma nova linguagem. Do mesmo modo, esperar que o uso de recursos de câmera e de cenário seja suficiente para estabelecer a linguagem fílmica é menosprezar a verdadeira dimensão artística do cinema (BAZIN, 1991, p. 131). Intimidado pela cristalização do espetáculo teatral no texto de O'Casey, o cineasta não encontrou a autonomia necessária para que seu processo criativo fluísse e não parece ter sido capaz de transpor para o cinema sutilezas e virtudes da obra literária. Se, por um lado, na postura de Hitchcock, transparece sua reverência pela arte de O'Casey, por outro, uma adaptação mais livre poderia talvez ter trazido maiores préstimos ao dramaturgo, uma vez que a associação a um filme "fiel", porém "medíocre", falaciosamente também atesta a mediocridade da peça que o originou.

Ainda que Hitchcock tenha empregado esforços na tentativa de abrilhantar sua produção, conforme fica claro na breve análise que realizamos acima, que atesta o domínio primoroso dos recursos cinematográficos, a união desses elementos não foi suficiente para resultar numa obra fílmica capaz de fazer jus às profundas significações implicadas na peça de O'Casey. Embora apresente grande valor histórico e até mesmo acadêmico, uma vez que constitui uma excelente fonte de estudos para questões de adaptação de obras literárias, Juno and the Paycock não possui grande perspectiva de sucesso com o 
público dos dias de hoje, já experimentado na linguagem amadurecida do cinema, que fulgura, inclusive, em obras posteriores do próprio Hitchcock. Se a dureza da crítica atual contradiz os elogios da crítica contemporânea ao filme, isso se deve ao fato de que, com o passar dos anos, o cinema pôde estabelecer sua autonomia enquanto arte, sem precisar das muletas do teatro para possuir um brilho próprio e original.

No que respeita ao próprio teatro, é de se esperar que uma forma artística fundamentada em uma tradição milenar e apropriada por um artista em tudo ciente do papel do dramaturgo como cronista dos tempos ofertese como uma representação profunda e comovente de uma práxis dramática que se faz trágica, justamente porque enquadra ações individuais na escala da vida social e política.

As opções de Hitchock pela tonalidade caricatural das personagens e pelo remate dos conflitos em suas dimensões existenciais dizem bem mais da ideologia implicada na produção do filme do que do tratamento concedido por O'Casey às ações e caracterizações. A considerarmos as obras em uma análise contrastiva, pode-se afirmar que O'Casey escreveu um drama social que acolhe a comédia e a tragédia, Hitchcock dirigiu uma farsa, um dramalhão. 


\section{Referências}

BAZIN, André. O Cinema - ensaios. Tradução de Eloísa de Araújo Ribeiro. São Paulo: Brasiliense, 1991.

BRITO, João Batista de. Imagens Amadas: ensaios de crítica e teria do cinema. São Paulo: Ateliê Editorial, 1995.

MORGAN, Jack. Alfred Hitchcock's Juno and the Paycock. In: Irish University Review, Edinburgh, v. 24, n. 2, p. 212-216, 1994. Disponível em: <http://www.jstor.org/stable/25484621>. Acesso em: 21 abril 2013.

MORRISON, James. Hitchcock's Ireland: The Performance of Irish Identity in "Juno and the Paycock" and "Under Capricorn". In: Jouvert, Raleigh, v. 4, n. 1, 1999. Disponível em: <http:// english.chass.ncsu.edu/jouvert/v4i1/jmorr.htm $>$. Acesso em: 21 abril 2013.

O'CASEY, Sean. Juno e o Pavão. Trad. Manuel Bandeira. São Paulo: Brasiliense, 1965.

ROHMER, Eric; CHABROL, Claude. Hitchcock, the first fortyfour films. New York: Frederick Ungar Publishing Co.,1979.

TRUFFAUT, François. Hitchcock/Truffaut. New York: Simon \& Schuster, 1985.

[Recebido em 30 de abril de 2013

e aceito para publicação em 16 de dezembro 2013] 